Dorota Kołodziejczyk

\title{
Poza metaforą - autyzm jako impas hermeneutyczny w powieści postkolonialnej
}

To jednak nie miejsce dla stów. Każdą wypowiedziana sylabę woda natychmiast porywa, wypetnia, rozprasza. Tutaj ciała same dla siebie sa znakami. To dom Piętaszka.

J.M. Coetzee, Foe

Mały twardy kamień, ledwo świadom swojego otoczenia, zatopiony w samym sobie $i$ we wtasnym życiu wewnętrznym. Przelatuje przez te zakłady, obozy, szpitale i Bóg wie co jeszcze niczym kamień. Przez kiszki wojny. [...] Michaels coś znaczy, a jego znaczenie nie ogranicza się tylko do mnie.

J.M. Coetzee, Życie i czasy Michaela K.

Postaci pozbawione możliwości komunikacji stanowią wyzwanie dla tekstu literackiego - czy wolno przemawiać w ich imieniu, skąd wiadomo, co w ich imieniu powiedzieć, i, być może przede wszystkim, czy taka postać w ogóle chce coś zakomunikować, czy nie wyobrażamy sobie woli wypowiedzi, której nie ma? Postaci $\mathrm{z}$ autyzmem - zaburzeniem rozwojowym, które może poważnie ograniczyć możliwości komunikacyjne bądź zupełnie je zablokować - w tekście literackim pojawiają się właśnie jako problem nieprzenikalności umysłu pozbawionego ekspresji werbalnej. Brak języka nie tylko blokuje komunikację, ale też, w konsekwencji, uniemożliwia przynależność społeczną - postać z autyzmem reprezentuje radykalną odmienność, ponieważ nie ma takiego systemu translacyjnego, który byłby w stanie przybliżyć jej sposób percepcji, widzenia świata i myślenia. Postaci o cechach autystycznych - niezdolne do ekspresji werbalnej, niezrozumiane przez otoczenie, nierozumiejące świata komunikacji, jakim jest świat społeczny - zajmują w fabule powieściowej przestrzeń braku. Nie są podmiotem, bo upodmiotowienie jest możliwe jedynie przez 
uczestnictwo w języku'; nie mają sprawczości, ponieważ nie są w stanie wyartykułować woli. Ich pojawienie się w tekście literackim z pewnością zmusza do postawienia pytań o miejsce osób tak niepasujących do neurotypowego pojęcia o przynależności, tożsamości i podmiotowości. Jednak pytania tego rodzaju są nie tyle celem, co wskazaniem celu w niniejszym artykule - prowadzą do jądra problemu, czyli fundamentalnej nieprzetłumaczalności umysłu działającego poza językiem i wynikających z tego impasu strategii przedstawieniowych, które muszą nadpisać nieprzetłumaczalność treścią. Postać z autyzmem - milcząca i wycofana jest więc brakiem, natomiast puste miejsce, które zostawia tam, gdzie powinna rozwinąć się podmiotowość (wola, sprawczość), zostaje wypełnione znaczeniami projektowanymi z zewnątrz. Semiotyka postaci $\mathrm{z}$ autyzmem $\mathrm{w}$ tekście literackim jest więc, można powiedzieć, wynikiem niezgody na nierozpoznane zna-

1 Teza o wejściu w język ( $w$ wyniku procesu separacji od matki - łożyska, i kastracji - uznania imienia Ojca) jako warunku wejścia w relacje społeczne, wynika oczywiście bezpośrednio z tradycji psychoanalitycznej [zob. Lacan 1973]. Z perspektywy psychoanalitycznej osoba autystyczna, w uproszczeniu, nie przeszła do porządku Symbolicznego i pozostaje w sferze Semiotycznego/Wyobrażeniowego. Gdyby odnieść się do tego założenia empirycznie, można by odczytać bliski związek artykulacji u osoby autystycznej (artykulacji, która nie musi, choć może, być wypowiedzią) z autostymulacją - powtarzaniem zbitek dźwięków lub słów, echolalaliami, dołączaniem do artykulacji ruchów ciała - jako specyficzną dla zaburzenia wersję pozostawania w sferze semiotycznej, rozumianej przez Kristevą jako pre-Edypalna faza rozwoju dziecka, w której słowo nie oddzieliło się od ciała, nie ma ja ani tożsamości, oraz, być może, nie przechodzi przez fazę lustra. Z drugiej strony, psychologia behawioralna nazwie tego rodzaju wnioski „mentalizmem” [Skinner 2013: 132-150] i udowodni, że wymienione objawy są skutkiem behawioralnego procesu (autostymulacje są wzmacniające; świadomości siebie można, do pewnego stopnia, nauczyć itd.). Psychoanaliza i psychologia rozwojowa to niełatwi partnerzy, głównie ze względu na przekonanie Lacana, że jego opis formowania się podmiotu nie jest sekwencyjny ani nawet „rozwojowy” i, w zasadzie, nie można go wywieść z empirycznych obserwacji, bo te są zawsze konstrukcjami społecznymi, a więc mediacjami pomiędzy niemowlęciem a jego matką [zob. Parker, 2015]. W niniejszym artykule opieram się na kategoriach lacanowskich przede wszystkim ze względu na to, że dostarczają one narzędzi do analizy języka jako władzy, prawa, i/lub przemocy, nie w empirycznych kategoriach odnoszących się do klinicznie zdiagnozowanej jednostki chorobowej. Podobnie autyzm w tekstach literackich, które analizuję, nie jest tematem ani nazwanym zaburzeniem, lecz wskazówką - nienazwaną enigmą - oraz tropem oddziaływującym na retorykę tekstu. 
czenie, zaś towarzysząca jej specyficzna poetyka niepokoju ma swoje źródło w poczuciu, że wszelkie metafory, mające na celu przypisanie podmiotu autystycznego do jakiejś (społecznej, kulturowej, etycznej) misji, są głęboko nieadekwatne jako strategie przekładowe - przybliżają coś, co w nieunikniony sposób cały czas się oddala.

To część ogólnego zagadnienia, jakim jest włączanie do literackiego świata przedstawionego postaci niepełnosprawnych, które przeważnie pojawiają się w tekście literackim nie tyle jako autonomiczne postaci, lecz jako sygnał problemu. Pojawienie się postaci niepełnosprawnej w tekście literackim prawie zawsze wywołuje refleksję na temat mechanizmów wykluczenia społecznego. Nie oznacza to, że wykluczenie jest zawsze przedmiotem negatywnej oceny - jeśli zrobilibyśmy przegląd reprezentacji osób niepełnosprawnych, zwłaszcza intelektualnie lub mentalnie, w powieści dziewiętnastowiecznej, okazałoby się, że wykluczenie (przeważnie zamknięcie lub inna forma odseparowania od „normalnego” społeczeństwa) jest traktowane jako racjonalny sposób na utrzymanie kontroli nad nienormatywnym zjawiskiem, jakim jest niepełnosprawność. Bez względu na implikowany w narracji stosunek do postaci niepełnosprawnej (przeważnie jest to współczucie z domieszką przerażenia, a nawet obrzydzenia, a więc odbiór bardzo afektywny), umiejscowienie jej w narracji literackiej odpowiada jej umiejscowieniu w społeczeństwie. Dla postaci niepełnosprawnej kreuje się w tekście osobną przestrzeń. Michel Foucault nazywa tę przestrzeń heterotopią dewiacji - miejscem dla działania podmiotu nienormatywnego, odbiegającego od obowiązujących w społeczeństwie zasad zachowań [Foucault 1984: 5], w tym wyglądu jako formy zachowania, które w tym przypadku odnoszą się do normy osoby zdrowej na ciele i umyśle, „nieuszkodzonej”. Dla podmiotu autystycznego pozostającego poza możliwością

2 Niepełnosprawność rozumiana jako uszkodzenie ciała lub umysłu jest charakterystycznym elementem medykalizacji myślenia o niepełnosprawności w społeczeństwie. Coś, co w uzusie medycznym może mieć neutralne znaczenie i odnosić się do organu, który nie funkcjonuje zgodnie z normą zdrowia, w szerszym polu semantycznym staje się znaczącym ustawiającym różnicę sprawny/niepełnosprawny hierarchicznie. 
komunikacji ${ }^{3}$ tworzona jest w narracji powieściowej heterotopia dewiacji, która bardzo silnie oddziałuje na całą strukturę tekstu, zaburzając jego podstawowy mechanizm ekspresji werbalnej opartej na wymianie między nadawcą a odbiorcą. Po drugie, przestrzeń ta tworzy dodatkowe wewnętrzne przestrzenie swojej funkcjonalności [Foucault 1984: 5-6], które z kolei odnoszą się do różnych warstw historyczności tej właśnie heterotopii. Krótko mówiąc, przestrzeń podmiotu autystycznego w narracji powieściowej ma funkcję podobną jak heterotopia niepełnosprawności - ma stawiać społeczeństwu pytania o jego normy, zasady i postawy etyczne wobec Innego, jakim jest osoba/postać niepełnosprawna. Owa heterotopia dewiacji-niepełnosprawności zachowuje w tekście literackim swoje uprzednie, jak zauważa Foucault, zadanie - jej podłożem jest heterotopia kryzysu [Foucault 1984: 4].

Specyfika postaci z autyzmem (klinicznie opisanym lub implikowanym jako zespół objawów) dodatkowo tę funkcję niepełnosprawności jako etycznego wyzwania wobec sprawnej normy wyostrza. Podczas gdy postać niepełnosprawna otwiera w tekście literackim problematykę marginesów na podobnej zasadzie, co inne mniejszości, proces uznawania marginesów i otwierania dla nich szerszej przestrzeni społecznej, która tak naprawdę jest przestrzenią podmiotowości, w przypadku postaci autystycznej może nie być dostępny. Postać $\mathrm{z}$ autyzmem nie jest bowiem w stanie włączyć się w społeczną interakcję przez język i komunikację werbalną4. Tak więc w swojej funkcjonalności narracyjnej interpelującego marginesu, która lokuje postać $\mathrm{z}$ autyzmem we wspólnej

3 Zaburzenie ekspresji mowy w autyzmie to szerokie spektrum odstępstw od norm komunikacyjnych - od pełnej zdolności korzystania z mowy werbalnej przy jednoczesnym zaburzeniu funkcji komunikacyjnych mowy (kłopot z rozpoznaniem poszczególnych funkcji języka w wypowiedzi, szczególnie tych, które kodują informację dotyczącą uczuć i ogólnie, odbioru i perswazji, czyli problem z funkcjami emotywną, konatywną i fatyczną, przez stadia pośrednie, aż po całkowity brak możliwości artykulacji i ekspresji, włączając w to samą zasadę komunikacji jako wymiany. Co ciekawe, u werbalnej osoby z autyzmem tak trudne funkcje języka jak metajęzykowa i poetycka nie muszą być zaburzone, o czym świadczy pisarstwo osób z autyzmem, szczególnie poezja, lub sam fakt, że niektórzy autyści z sukcesem uczą się języków obcych.

4 Oczywiście, systemy komunikacji zastępczej, jak na przykład język migowy, są pełnoprawnymi systemami językowymi - same w sobie powstały po to, aby 
przestrzeni heterotopii dewiacji z innymi niepełnosprawnościami, postać ta ma funkcję perswazyjną - uświadamia czytelnikowi/ społeczeństwu, że wykluczenie czy odsunięcie na marginesy jest niesłuszne, że potrzebna jest społeczna melioracja tego stanu. Jednak postać z autyzmem kreuje dodatkowy efekt, który zaburza obietnicę naprawczej roli narracji, a tym samym zaburza porządek symboliczny procesu narracyjnego. Źródłem tego zaburzenia jest brak możliwości przejścia przez postać z autyzmem procesu upodmiotowienia. Autysta nie stanie się „ja”, ponieważ stan ten czy, raczej, funkcja językowa (a z nią społeczna) podmiotu wymaga uczestnictwa w procesie komunikacji językowej. Postać z autyzmem, bardziej nawet niż postać z (jedynie) niepełnosprawnością intelektualną, sama nie poddając się procesowi symbolizacji do pozycji podmiotu, pozostaje potencjalnym obiektem zawłaszczeń do wyobrażeniowych lub symbolicznych porządków tworzonych w języku, a zwłaszcza w jego specyficznym przypadku, jakim jest sztuka werbalna, czyli literatura.

Wprowadzenie do tekstu literackiego postaci o cechach autystycznych wymusza więc zastosowanie strategii przedstawieniowych, które mają tę postać po prostu opowiedzieć, ale w taki sposób, aby jak najbliżej dotrzeć do jej ja, myśli i uczuć. Lecz strategie te nie mogą być niczym więcej niż albo aproksymacją podmiotu autystycznego, albo jego zawłaszczeniem, nawet jeśli najbardziej etycznym w zamiarze. W samym sercu problemu reprezentacji: obecności i, być może, upodmiotowienia (zastępczego, wyobrażeniowego, symbolicznego) postaci z autyzmem, kryje się kwestia świadomości i woli jako warunków niezbędnych do zaistnienia komunikacji. Lecz trzonem kompleksu autystycznych zaburzeń jest właśnie deficyt auto-świadomości i woli5. Niemożność wyra-

wprowadzić grupę niepełnosprawnych - głuchych - do sfery podmiotowości opartej na komunikacji werbalnej.

5 Jednym ze sposobów diagnozowania autyzmu jest sprawdzenie posiadania przez osobę diagnozowaną tak zwanej „teorii umysłu”. Jeśli osoba z autyzmem, w tym przypadku koniecznie posługująca się językiem, nie jest w stanie przypisać innym potencjalnych stanów mentalnych - na przykład wyobrazić sobie, jakie uczucia $\mathrm{w}$ interlokutorze wzbudza informacja lub inna wypowiedź, odczytuje się to jako objaw zaburzenia autystycznego i przypisuje typowemu dla tego zaburzenia wycofaniu ze świata wzajemności, jakim jest świat społeczny. Rzecz jasna, teoria 
żenia siebie poprzez działanie za pomocą siły sprawczej języka stanowi główną zagadkę autyzmu tak w sensie klinicznym, jak i w literackich próbach przybliżenia tej radykalnej inności. Autyzm jest radykalnym odstępstwem od naszego rozumienia tego, co substancjalnie ludzkie: w literaturze (bo zajmujemy się reprezentacjami, nie zaś klinicznymi omówieniami) i kulturze postać $\mathrm{z}$ autyzmem egzystuje poza wiążącą społecznie przestrzenią języka, a tym samym poza jego trzema powiązanymi sferami działania: komunikacji, wyobraźni i sprawczości (podmiotowości). W konsekwencji postać z autyzmem pozostaje na granicy (nie) ludzkiego, podważając fundamentalne wyprowadzanie wyjątkowości ludzkiego gatunku z faktu posiadania języka:

Być ja i stać się ja to wejść w sieci rozmowy; wiedzieć, jak odpowiedzieć, gdy ktoś się do mnie zwraca, i wiedzieć, jak się zwrócić do innych. [...] Wradzamy się w sieci rozmowy lub narracji, począwszy od tych, które odnoszą się do rodziny i płci kulturowej, po makronarracje tożsamości zbiorowej. [Benhabib 2002: 15, przeł. D.K.]

A zatem, czy człowiek bez języka, poza tym, co Benhabib nazywa „interakcyjnym uniwersalizmem” [Benhabib 2002: 14], poza logosem, pozostający zarówno poza światem społecznym, jak i metafizyką, spełnia kryteria tego, co ludzkie? Jeśli opis uniwersalności ukazuje zmarginalizowanie grupy społecznej do hetertopijnej sfery nieokreślonego nieprzynależenia, być może trzeba szukać adekwatnego języka opisu tej sytuacji poza dyskursem o prawach jednostki, opartym na logosie, i wypracować sojusz z dyscyplinami, które wyodbywają podmiotowość spod nawarstwień dyskryminacji, jak na przykład studia nad zwierzętami i, ogólnie, ekokrytyka [zob. np. Huggan, Tiffin 2015, Glotfelty, Fromm 1996, Moe 2016]? Ato Quayson podkreśla, że nieprzynależność do ludzkiego świata z jednej

umysłu wydaje się opisywać bardziej skutki niż przyczyny zaburzenia - z perspektywy choćby psychoanalizy lacanowskiej podmiot, który nie przeszedł do porządku symbolicznego, nie będzie w stanie budować siatki znaczeń w dialogu $\mathrm{z}$ innym podmiotem, ponieważ nie spełnił warunku skonstruowania swej podmiotowości przez różnicujący kontakt $\mathrm{z}$ innym. 
strony zbliża podmiot autystyczny do świata zwierząt, a z drugiej, ta nieprzynależność ostatecznie każe jemu samemu sklasyfikować się jako przypadek pod-ludzki [Quayson 2007: 171]. Przedstawienie tej nieprzedstawieniowej sytuacji: między ludzkim, nie-ludzkim i pod-ludzkim - skazuje autora takiego przedsięwzięcia na niepowodzenie i to właśnie owo niepowodzenie - zaznaczenie go, przyznanie się do niego, wręcz wyznanie go jako winy autora, który musi zawłaszczyć, zamknąć bezbronny podmiot w swoim wyobrażeniu, wymyślić go bez jego potencjalnie polemicznego udziału jest motorem tworzenia nowej retoryki nieprzedstawialności, która czyni obecność postaci autystycznej w tekście możliwą.

Nie wszędzie oczywiście ten rodzaj etycznej rozterki będzie widoczny w próbach przedstawienia postaci o cechach autystycznych. Nie jest tym samym moim zamiarem rozwinięcie w niniejszym tekście ogólnej teorii reprezentacji postaci z autyzmem, przede wszystkim dlatego, że różne byłyby to strategie w zależności od gatunku narracji fikcjonalnej. W badaniach na temat reprezentacji postaci $\mathrm{z}$ autyzmem $\mathrm{w}$ kulturze dominuje skupienie na funkcjonalności tych postaci dla całego układu narracyjnego powieści bądź filmu. Mark Osteen w Autism and Representation [2008] i Stuart Murray w Representing Autism. Culture, Narrative, Fascination (2008) klasyfikują owe funkcje według kategorii (wyobrażeniowe: przejścia/portale do innego świata, amelioracyjne społecznie, funkcja testu etycznego, kulturowy stereotyp - idiota/savant, przestrzeń abiektowej potworności itd.) oraz według ich historycznej zmienności. W krytyce z obszaru studiów nad niepełnosprawnością dominuje z kolei konstruktywistyczne podejście do kwestii niepełnosprawności, w których jest ona umiejscawiana w kontekstach politycznych, społecznych i kulturowych jako kategoria, która ulegała transformacjom w czasie, a więc jest pojęciem historycznie zmiennym [Davis 2015: xvi], wywiedzionym z fizycznego bądź mentalnego/intelektualnego deficytu osób niespełniających normy sprawności ${ }^{6}$ Kategoria

6 Analiza korpusu języka odnoszącego się do niepełnosprawności jest ciekawym polem badawczym: jak się ma kalectwo do niepełnosprawności w uzusie (historycznie, afektywnie); dlaczego badany korpus dostarczy nam więcej przypad- 
niepełnosprawności, która wywodzi się z dziewiętnastowiecznej kategorii dewiacji (tutaj widzimy już dlaczego dewiacja ma swoją „inną” przestrzeń - Foucault rozwinął teorię heterotopii również w oparciu o badania nad powstaniem kliniki), służyła, jak pokazuje Lennard J. Davis, kształtowaniu pojęcia normalności w opozycji do „dewiacyjnych” przypadków ciała i ducha [Davis 2015: 10-11]. Skonstruowanie pojęcia niepełnosprawności oraz jego symboliczna dystrybucja w społeczeństwie, która kodowała niepełnosprawność jako klasową podrzędność, a wręcz kazała upatrywać źródeł kryminalnych form dewiacji społecznych w psychicznym bądź fizycznym odstępstwie od normy, było niezbędne do rozwinięcia państwowej biopolityki, jak pisze Tobin Siebers, rozwijając koncepcję Foucaulta:

Techniki biowładzy - statystyka, demografia, eugenika, medykalizacja, sterylizacja - są dobrze znane badaczom niepełnosprawności. Biowładza określa dla Foucaulta sposób, w jaki podmioty ludzkie doświadczają materialności ciała. Zanim nie zaistnieje upodmiotowienie jako reprezentacja, podmiot ludzki nie ma ciała ani też nie istnieje jako podmiot. [Siebers, 2015: 174, przeł. D.K.]

Siebers zauważa, że marginalizacja podmiotów niepełnosprawnych jako niespełniających normy wyznaczonej przez biopolitykę czyni z nich podmioty niepełne lub jeszcze-nie-podmioty, i proponuje łączyć tę marginalizację, którą za Foucault określiliśmy jako heterotopię, z kategorią ciała abiektowego Judith Butler:

[...] wykluczająca matryca, według której kształtowane są podmioty, wymaga jednoczesnego wytwarzania sfery bytów

ków metaforycznych zastosowań oznaczeń niepełnosprawności niż odniesień do rzeczywistych przypadków? Jak ocenić fakt, że większość metaforycznych zastosowań kategorii niepełnosprawności ma negatywne referenty? Ślepy, głuchy, ktoś/coś specjalnej troski, autystyczny - to są zastosowania oparte o kliniczne kategorie, ale w metaforyce języka odnoszące się do zjawisk negatywnych: głuchy na prośby, ślepy na sygnały oraz ciekawe zastosowanie w dyskursie politycznym: „państwo specjalnej troski”. 
abiektowych, takich, które jeszcze nie są podmiotami i tworzą konstytutywne zewnętrze w relacji do sfery podmiotu. [Butler 1993: 3]

Konstruktywistyczna krytyka niepełnosprawności w dyskursie społecznym, politycznym i medycznym koncentruje się na analizie i ocenie mechanizmów pozycjonowania niepełnosprawności jako inności względem normy. Jak pisze Ato Quayson:

[...] odnosimy kategorię niepełnosprawności nie tyle do pojęcia ograniczonej pełnosprawności spowodowanej jednostką kliniczną, lecz do zastanego społecznego środowiska, które dla osoby niepełnosprawnej generuje trudności. [Quayson 2009: 15, przeł. D.K.]

To, co może się w tej definicji wydawać próbą zanegowania niepełnosprawności jako faktu diagnostycznego, czyli radykalne zrelatywizowanie jej jako wyobrażenia inności, jest w istocie kluczowym odwróceniem perspektywy, w której to nie inność podmiotu niepełnosprawnego, lecz niedogodności środowiska, które są codziennym doświadczeniem osoby niepełnosprawnej, stają się obszarem interwencji krytycznej. W ten sposób, kontynuuje Quayson, niepełnosprawność przestaje być wyłącznie „wytworem tragicznych okoliczności”, dostosowanie do których jest głównie odpowiedzialnością osoby niepełnosprawnej i/lub jej opiekunów i rodziny. Staje się wspólnotową odpowiedzialnością za dostosowany do potrzeb każdej niepełnosprawności program włączający do aktywnego uczestnictwa w życiu społecznym. W tym sensie konstruktywistyczna perspektywa disability studies ma potencjał rozwijania umiejętności etycznego dzielenia się przestrzenią sprawczości. Pojawiają się jednak głosy krytyki, które zwracają uwagę, że koncentracja na krytyce struktur, w których osoby niepełnosprawne muszą funkcjonować, może blokować refleksję o niepełnosprawności jako realnej życiowej kondycji. Mark Osteen w książce Autism and Representation (2008) ocenia niechęć studiów nad niepełnosprawnością do uznania medycznej podstawy kategorii niepełnosprawności jako błąd tak 
w sferze naukowej (nie da się oddzielić niepełnosprawności od faktu ubytku na zdrowiu), jak i w sferze etycznej, która jest przecież priorytetem konstruktywistycznych badań w tym obszarze. Odmowa dostrzeżenia w niepełnosprawności substancjalnej treści i traktowanie jej jako zbioru relacji oraz efektu społecznej polityki państwa prowadzi, jak argumentuje Osteen, do marginalizacji tych aspektów niepełnosprawności, które stanowią albo przyczynę niepełnosprawności (stan medyczny), albo wyróżnik życia z niepełnosprawnością, którymi nierzadko są jak najbardziej fizyczny ból i cierpienie:

Społeczno-konstruktywistyczne modele niepełnosprawności paradoksalnie uniemożliwiają studiom nad niepełnosprawnością teoretyzację istotnych dla niepełnosprawnych osób problemów: bólu, cierpienia i ograniczeń zdrowotnych [impairment]. [Osteen 2008: 8, przeł. D.K.]

Literackie i kulturowe przestawienia niepełnosprawności wprowadzają do treści dzieła mechanizmy afektywno-kognitywne, które ujawniają, jak pisze Quayson, „impas hermeneutyczny”, powstały w wyniku konfrontacji normalności z niepełnosprawnością, który można zdefiniować dosłownie jako zablokowaną ścieżkę odczytania tekstu: „Na każdym poziomie naszych prób rozpracowania tekstu stajemy wobec problemu struktury interpretacji. Wszystko wydaje się labilne i nieuchwytne" [Quayson 2009: 64; 49-52]. W przypadku niepełnosprawności intelektualnej, a zwłaszcza niepełnosprawności mocno ograniczającej lub uniemożliwiającej komunikację, jaką jest autyzm7, umiejscowienie takiej postaci poza działaniem języka narzuca konieczność budowania struktur kompensacyjnych, aby przedstawienie było w ogóle możliwe. Ów impas hermeneutyczny, wynikający z trudności

7 Oczywiście, w terapii klinicznego autyzmu nie można mówić o zupełnym braku komunikacji - u najbardziej zaburzonych w tym zakresie osób terapia zawsze jest w stanie wypracować choćby minimum komunikacyjnych zachowań (jeśli nie wyrażenie woli przez gest lub wydanie dźwięku, to przynajmniej podstawowe reakcje na bodźce komunikacyjne otoczenia, werbalne lub inne). Oczywiście, można się zastanawiać, czy jednostronna komunikacja jest komunikacją, czy tylko uwarunkowaną reakcją na bodźce zewnętrzne. 
w określeniu roli postaci niepełnosprawnej w świecie społecznym (w tym świecie przedstawionym), funkcjonuje jako swego rodzaju przedpole fundamentalnego kryzysu reprezentacji ujawniającego się wraz z wprowadzeniem postaci niepełnosprawnej do tekstu, szczególnie narracji fikcjonalnej. Mark Osteen w cytowanej wyżej książce zauważa, że ów kryzys reprezentacji ma swoje źródło w sferze społecznego odbioru niepełnosprawności „Niepełnosprawności kognitywne reprezentują zakłócającą siłę, która stawia wyzwanie naszemu pojęciu inteligencji, sprawczości, oraz tego, co to znaczy być człowiekiem" [Osteen 2008: 6, przel. D.K.]. Podobnie Stuart Murray w swoim studium kulturowych reprezentacji autyzmu, Representing Autism, podkreśla, że graniczność postaci z autyzmem jest źródłem fascynacji, która wyraża się w formie dyskursu wiedzy i mistyki jednocześnie, „w taki sposób, aby procesy wnikania w autyzm, strachu oraz pragnienia mogły współegzystować" [Murray 2008: 13, przel. D.K.]. Pozostawanie na granicy (nie)ludzkiego - poza komunikacją, a tym samym poza sprawczą siłą języka, poza możliwościami rozwinięcia (pełnej, a czasem nawet minimalnej) struktury samoświadomości, która zawsze jest społecznie kształtowana ${ }^{8}$, sprawia, że postać $\mathrm{z}$ autyzmem uwalnia w tekście charakterystyczną poetykę niepokoju i niepewności, a na poziomie symboliki staje się figurą inności, umieszczoną w spektrum między potworem a aniołem. Funkcjonalność tej figuratywnej z definicji postaci jest zazwyczaj dwubiegunowa: postać autystyczna (w tym też intelektualnie niepełnosprawna) jest zarówno kozłem ofiarnym, jak i świętym, niczym archetypalny wiejski głupek z obrazu Chagalla.

Zakłóceniowa i interpelacyjna funkcja postaci autystycznej $\mathrm{w}$ warstwie retorycznej tekstu oraz jej rola ofiarna i ekspiacyjna

8 Nie mam ani kompetencji, ani miejsca w tym artykule, aby przytoczyć choćby podstawy debaty na temat relacji i powiązań umysłu i świadomości, szczególnie tego, jak nowe odkrycia w medycynie, biologii, zoologii, kognitywistyce oraz nowe technologie zmieniają naszą wiedzę na temat podmiotowości, umysłu, programów kodujących, jakimi się posługujemy w naszej percepcji (w tym języka), czy działania afektów na świadomość. Autyzm na pewno w wielu przypadkach podważa wzajemną korelację umysłu i świadomości, jako zaburzenie, które, na przykład, według teorii umysłu, polega na deficycie świadomości siebie, a przez to świadomości tego, jak myślą i czują inni. 
w warstwie symboliki rozwijają się, jak zauważa Quayson, na gruncie charakterystycznej poetyki, która wyrasta z impasu hermeneutycznego wytworzonego przez konfrontację normy z niepełnosprawnością. Jest to poetyka „nerwowości estetycznej”, uwalnianej, „gdy w dominujących regułach przedstawieniowych w tekście literackim następuje zwarcie $\mathrm{w}$ odniesieniu do niepełnosprawności” [Quayson 2007: 16]. Quayson dostrzega w owej poetyce „Zwarcia” zakodowaną rzeczywistą reakcję społeczną na niepełnosprawność (patrzeć/nie patrzeć? Zauważyć niepełnosprawność czy zachowywać się, jakby jej nie było?). Poetyka nerwowości estetycznej nie jest więc do końca świadomą strategią autora, który wdraża ją, aby jak najpełniej wykorzystać potencjal, jaki niesie ze sobą wprowadzenie do tekstu postaci niepełnosprawnej. Jest to raczej przestrzeń zakłóceniowa, którą można porównać z impasem translacyjnym, gdy tłumacz zdaje sobie sprawę, że w przekładzie musi zgubić taką część oryginalnego tekstu, którą uznaje za dogłębnie, a nawet intymnie, oddającą jego istotę. W przypadku postaci autystycznej impas hermeneutyczny jest również problemem translacyjnym - brak wspólnego kodu uniemożliwia komunikację między postacią autystyczną i społeczeństwem, zaś poetyka nerwowości estetycznej brak ten zarówno ujawnia, jak i stara się uzupełnić. W literaturze postkolonialnej postaci niepełnosprawne intelektualnie, z których wiele ujawnia cechy autystyczne, mają zazwyczaj wyraźną funkcję, wpisującą się w model „alegorii narodowej" - tendencji, przypisywanej literaturze Trzeciego Świata przez Fredrica Jamesona, do nadpisywania treści powieści alegorycznym obrazem narodowej wspólnoty [Jameson 1986, 65-88]. Postaci o cechach autystycznych w powieściach Salmana Rushdiego (Wstyd 1982, Ziemia pod jej stopami, 200o), Amitava Ghosha (Koło rozumu 1986, Żarłoczny przypływ 2004), Rohintona Mistry (Such a long journey 1991), i, przede wszystkim, J.M. Coetzeego (Czekajac na barbarzyńców 1980, Życie i czasy Michaela K. 1983, Foe 1986) są częścią alegorycznego obrazu zbiorowości i/lub władzy, lecz ich niepełnosprawność, która ani nie prowadzi do procesu upodmiotowienia (nie jest autonomicznym tematem), ani nie „wyzwala” podmiotu z niepełnosprawności, przedstawionej jako brak, ograniczenie, uwięzienie, ma spełniać rolę „narracyjnej 
protezy" [Mitchell, Snyder 2006: 207] - mechanizmu, za pomocą którego narracyjna całość - alegoria narodowa - zyskuje dodatek metaforyczno-ekspiacyjny. Lecz ponieważ owa „proteza narracyjna” ma ambiwalentny efekt dla całości opowieści tworzącej alegorię, postaci niepełnosprawne w ostateczności zakłócają spójność dyskursu narodowego (dyskursu państwa, władzy). A ściślej, postaci te same stają się przedmiotem kontroli ze strony biowładzy, która je klasyfikuje, formuje ich ciała i umysły oraz wyznacza im miejsce na marginesie przestrzeni społecznej i przestrzeni państwa. Ich bierność, wynikająca z braku możliwości wyrażenia woli, pozwala biowładzy się umacniać i legitymizować. Jednocześnie postaci te są z zasady siłą zaburzającą działanie biopolityki i autorytet biowładzy, ponieważ ich obecność w tekście literackim zawsze jest ideologicznie naznaczona [Davis 2006: 15] - zawsze podnosi problem konstytuowania się hegemonii i podległości w społeczeństwie, tutaj głównie jako wynik zagospodarowania pojęcia niepełnosprawności dla umacniania pojęcia normy (patologizacja niepełnosprawności, marginalizacja jej jako problemu, marginalizacja jako przesunięcie działania podmiotu niepełnosprawnego na obrzeża społeczeństwa, zamierzone utrzymywanie graniczności znaczeń niepełnosprawności intelektualnej na styku ludzkie/nieludzkie itd.). Enigma, jaką pozostaje postać z autyzmem, uruchamia coś, co proponuję określić jako hermeneutyczną mobilizację tekstu, wywołaną przez „niepokój estetyczny” - afektywne poruszenie na skutek kontaktu z radykalnym Innym, który uświadamia nam, że, tak samo jak jego niepełnosprawność, nasza pełnosprawność jest kwestią przygodności [Quayson 2007: 21]. W tym sensie postać z autyzmem jest w tekście literackim, tutaj szczególnie postkolonialnym, narzędziem rewizji znaczeń budowanych wokól pojęcia wspólnoty i narodu.

Choć tekst Jamesona wywołał falę krytyki w konsolidujących się wówczas studiach postkolonialnych, ponieważ dzielił literaturę na estetycznie wyrafinowaną literaturę Zachodu i prostą, ale politycznie zaangażowaną literaturę Trzeciego Świata, jego teza o alegorii narodu jako swego rodzaju horyzoncie polityczno-historiograficznym scalającym tekst wychodzi poza kontrowersyjne przykłady i dobrze oddaje fundamentalną cechę literatury post- 
kolonialnej, szczególnie na jej wczesnym etapie, gdy wyraźnie dominuje w niej wyobrażeniowy wysiłek, jakim jest dążenie do zbudowania koncepcji narodu. Dzieci pótnocy Rushdiego to deklaratywna wręcz alegoria narodowa. Niestety, powieść ta niewiele ma wspólnego z estetyczną klasyfikacją zaproponowaną przez Jamesona. Wyznacza ona za to kierunek dla przyszłych alegorii narodowych w powieści postkolonialnej - naród jawi się w niej jako wyobrażeniowy horyzont, nigdy jako gotowy emblemat; naród jest konstruktem historiograficzno-politycznym, który zawsze pozostaje dyskursywny, a więc jego fundamentalną cechę stanowi wewnętrzny konflikt, często realizowany jako dialektyczne ścieranie się różnic (np. projekt natywistyczny vs. projekt obywatelski). Jako taki, naród jest alegorią samopodważającą się w tym sensie, że jego potencjalną emblematyczność, czyli semantyczną kompletność, rozbija ironia jego retoryczności. Bez względu więc na treść narodowych wyobrażeń w powieści postkolonialnej istotną rolę odgrywa poetyka rozwijanej w tekście alegorii narodu: naród jest stale wymykającym się domknięciu produktem fantazji społecznej, przedmiotem pożądania, który łatwo może zmienić się z sublimowanego ideału w Realne - pozornie substancjalną potworność, która tak naprawdę przykrywa tylko fakt nieuchronnego niepowodzenia Symbolicznego. Lacanowska rama interpretacyjna dla materialistycznej koncepcji alegorii narodu Fredrica Jamesona pozwala efektywnie odczytać niekompletność emblematu narodu, który budowany jest $\mathrm{z}$ lańcuchów fantazji, maskujących arbitralność i wirtualność jego symbolicznego wymiaru. Sama retoryczność, która nie pozwala na zamknięcie narodu w gładki emblemat, jest raczej skutkiem niż powodem fundamentalnego pęknięcia alegorii narodowej. Realne narodu, które wdziera się do jego symbolicznego wymiaru, na poziomie formalnym realizowanego jako alegoria, ujawnia się jako nieuchronnie powracająca, wyparta i wypierana, potworność, maskowana przez wyobrażeniowe obrazy. Postać niepełnosprawna jest takim, pełnym paradoksów, Realnym potwornym alegorii narodowej ${ }^{9} \mathrm{w}$ lite-

9 Film animowany Beowulf, reż. Robert Zemeckis, scenariusz Neil Gaiman, Roger Avary, Shangri-La, Entertainment ImageMovers, 2007, oparty na eposie sta- 
raturze postkolonialnej. Prawie zawsze ma ona za zadanie burzenie pozornie nieskomplikowanego i kompletnego obrazu narodu. Na poziomie retoryczności tekstu postać niepełnosprawna jest źródłem „nerwowości estetycznej”, która nie dopuszcza do poczucia estetycznej i semantycznej pełni w rozwijanej w tekście alegorii narodu. Stanowi więc element zakłócający dobrostan narodowej spójności - niebezpieczny margines, przestrzeń, w której komplikują się znaczenia pozornie już wypracowane. W literaturze postkolonialnej postać niepełnosprawna intelektualnie, zwłaszcza taka, która pozostaje poza społecznie konstytutywną sferą komunikacji, narusza patos alegorii narodu, odkrywając to, co dyskurs narodu wyklucza, ukrywa i wypiera, aby osiągnąć wrażenie tożsamościowej pełni i ideologicznej racji. Inny nie zaburza znaczeniem przeciwnym, opozycyjnym, nie podważa samej substancji znaczenia narodu. Jego niebezpieczne działanie polega na tym, że pod powierzchnią swojej nieczytelności (nieprzeniknione spojrzenie Piętaszka w Foe; niewiadoma istota barbarzyńskiej dziewczyny, okaleczonej przez funkcjonariuszy Imperium w Czekając na barbarzyńców Coetzeego, niewyartykułowany afekt Sufiji Zinobii we Wstydzie Rushdiego; wycofanie w świat afazji i obsesji na punkcie maszyny i jej ducha w Kole rozumu Amitava Ghosha), ukazują pustkę. Ta pustka to wynik interpretacyjnego wysiłku poznania i uznania Innego. Nie znaczy to, że postać niepełnosprawna intelektualnie nie ma znaczenia, lecz że nie da się jej odczytać według dostępnych kodów. Wysiłek interpretacyjny postaci, która bierze na siebie misję uratowania osoby skrajnie podrzędnej poprzez odzyskanie jej znaczenia, lub podejmującego się tego głosu, staje wobec prawdy, że przedsięwzięcie to ma na celu uratowanie siebie od poczucia winy, świadomości własnej pustki i, ostatecznie, narzucenia własnego, arbitralnego odczytania Innego zgodnie z własnym scenariuszem oczekiwań. Tymczasem Inny pozostaje poza zasięgiem kodów wpisujących się w ramę alegorii i, jako taki,

roangielskim, przedstawia potwora zagrażającego wspólnocie jako niepełnosprawne, zdeformowane ciało. Wizualnie połączono w nim motywy plastynacji von Hangensa z obrazem porażenia mózgowego. Beowulf nie jest po prostu zawsze ewentualną, zewnętrzną potwornością, lecz wypartą potwornością samej wspólnoty - jest odrzuconym synem króla, a więc powraca jako wyparty Inny. 
staje się jej Realnym - ukazuje ją samą jako fikcję, czyli realizację pragnienia przez wytwarzanie zawsze nowych wyobrażeń.

Wstyd Salmana Rushdiego jest powieścią, w którą deklaratywnie wpisana jest alegoria narodu, budowana na kanwie baśni o Pięknej i Bestii. Z tym że to baśń palimpsestowa - Piękna to zarazem Śpiąca Królewna, postać niepełnosprawna intelektualnie. Bohaterka powieści, Sufija Zinobia, córka generała Razy Hajdera, płonie ze wstydu za każdym razem, gdy władza wykonuje kolejny krok ku autokratyzmowi. Narrator-autor nazywa ją „bohaterką peryferyjną”, bo, jako osoba głęboko niepełnosprawna intelektualnie w Pakistanie, jest wstydem matki i hańbą rodziców, „mylnym cudem” [Rushdie 2000: 106] ${ }^{10}$. Sufija jako osoba wycofana i reagująca na otoczenie jedynie afektem (wstydem, czasami gniewem) staje się miejscem na wyparte ze świadomych działań władzy poczucie wstydu - bierze na siebie hańbę państwa i wstyd, którego władze nie chcą odczuwać. Państwo oparte na grzechu („Peccavistan” [Rushdie 2000: 105]) i wypartym wstydzie dąży prosto do apokalipsy - Sufija przechodzi transformację ze Śpiącej Królewny w Bestię i, zamieniając wstyd na płonący gniew, uosabia karę spadającą na bezwstydny Pakistan. W innych powieściach Rushdiego postaci niepełnosprawne intelektualnie, podobnie jak we Wstydzie, służą jako przejścia do innych, alternatywnych światów - są tajemnicze i niezgłębione, ponieważ być może za ich wycofaniem ze świata rozumu i deliberacji kryje się sprawczość o wiele bardziej potężna [Ziemia pod jej stopami 20oo]. Alegoryczność narodu jako jedności z wielości, ideał, który, przeniesiony na grunt Indii i Pakistanu w powieściach Rushdiego, ukazuje się jako wielowarstwowy postulat, podszyty ironicznym rozchwia-

Bardziej adekwatnym tłumaczeniem byłoby „cudem, który się nie udał” / nieudanym cudem” [oryg. „a miracle that went wrong”], jako że Sufija Zinobia nie dość, że, wbrew oczekiwaniom, nie była chłopcem, to jeszcze okazała się niepełnosprawna intelektualnie. „Mylny cud” podkreśla poczucie omyłki losu, zaprzepaszcza znaczenie oczekiwań zainwestowanych w dziecko, tego, że Sufija nie udała się jako cud, którym miała być. Oczywiście, znaczenia puszczone w ruch komplikują się, ponieważ „nieudany cud” działa jednak w sferze cudowności, więc to, co dla rodziców jest czymś „nieudanym” - płeć i niepełnosprawność córki - w planie narracyjnym pozostaje w sferze cudowności, która pozwala działać prawdzie, blokowanej w przestrzeni normy. 
niem znaczeń, skonfrontowana zostaje $\mathrm{z}$ alegorią wypartego, ale niezbędnego, marginesu.

W powieści J.M. Coetzeego Życie i czasy Michaela K., tytułowy bohater, niepełnosprawny intelektualnie i rasowo dyskryminowany, którego tożsamość zaznaczona jest jedynie jako przypadek policyjno-kliniczny, ucieka z obozu dla takich jak on marginesów społeczeństwa (marginesy są tak szerokie, że obozy wydają się zajmować coraz więcej miejsca w policyjnym państwie) i zaczyna wieść proste życie, uprawiając na niezagospodarowanym terytorium ogród. Alegoria RPA nie jest jednak tak prosta, jak mogłoby się wydawać - uprawianie ogrodu poza obozem internowania niepożądanych elementów społecznych mogłoby zostać łatwo uznane za udaną alegorię ucieczki do strefy wolności w naturze, lecz w rzeczywistości stanowi obszar zupełnego wykluczenia. $\mathrm{Z}$ tego miejsca wolność nie ma znaczenia, bo nie jest postulatem czy obiektem walki. Brak nadzoru państwa to jeszcze nie wolność. Michael K. nie potrzebuje, a przede wszystkim nie pragnie, wolności, lecz przeżycia, a uprawianie ogrodu na porzuconej farmie to zajęcie, które pozwala mu wolniej iść ku śmierci, do której jednak się zbliża. Niepełnosprawność intelektualna Michaela K., której cechy wskazują na autyzm, nie pozwala mu skonstruować swojej opowieści; jego autoprezentacja to stałe powtarzanie jednej frazy: ,jestem ogrodnikiem”. Sugerowana opozycja państwo (społeczeństwo, kultura)/natura (ogród, Michael K., utożsamianie się z byciem ogrodnikiem, przynależenie do ziemi, do matki [Masłoń 2009: 83]), gdzie natura staje się przestrzenią wolności jako sprawczości, to pułapka interpretacyjna powieści Coetzeego. Wolność poza społeczeństwem to wykluczenie, przestrzeń bytowania poza językiem to rozpad świadomości siebie ${ }^{11}$, a to z kolei, i warunki środowiskowe, skazuje Michaela K. na pozostawanie w granicznej strefie między życiem a śmiercią, w strefie przeżycia. Tak więc historia Michaela K. zaburza alegorię, którą ma budować - alegorię zwycięstwa nad uciemiężeniem przez ucieczkę do natury i odnalezienie w niej wolności - ale też buduje kontr-alegorię, 
niejako paradoksalnie, ponieważ poza metaforyczną funkcjonalnością postaci intelektualnie niepełnosprawnej. To kontr-alegoria metonimii - Michael K., jako niepełnosprawny intelektualnie i rasowy Inny reprezentuje przestrzeń wykluczenia - jeśli Inni mogą nawet być kojarzeni ze społeczeństwem, to skojarzenie to nie jest pożądane, nie stanowią więc części całości (synekdochy), lecz przesunięcie prawidłowego znaczenia. To metonimia marginesów - przestrzeń nieprzynależenia, która nie może reprezentować siebie tylko wykluczającą całość. Jako taka podważa ona również fundamentalną cechę alegorii narodowej, jaką jest jej zakorzenienie w historii, sprzeczne o tyle, że alegoria historię zamyka w emblematycznym obrazie. Przypadek Michaela K. pokazuje, że postaci tej nie da się uchwycić w alegorii jednostki uciemiężonej przez aparat imperialnej władzy -Quayson zaznacza w swoim studium powieści Coetzeego, że co prawda postać Michaela K. jest skonstruowana tak, aby stanowić łatwy materiał do alegoryzacji, lecz, z drugiej strony, jego graniczny status nie/ ludzkiego stanowi swoistą blokadę dla upolitycznienia czy ideologizacji tej postaci. W tym sensie alegoria, historyczność i polityczność pozostają fundamentalnie rozłączne [Quayson 2007: 174].

Trzy powieści Coetzeego, w których postać niepełnosprawna z cechami autyzmu bądź oznakami zaburzenia ekspresji mowy, czyli Czekając na barbarzyńców, Życie i czasy Michaela K. oraz Foe, napisane jedna po drugiej, tworzą w moim przekonaniu etyczną wykładnię myśli autora. W każdej z nich postać ta jest ofiarą biowładzy - jako więzień w Czekając na barbarzyńców, więzień-uciekinier i pacjent w Życie i czasy Michaela K. oraz jako służący-niewolnik, Piętaszek, w Foe. W każdej z tych powieści bohater naznaczony autyzmem dostaje się pod opiekę osoby, która pragnie poznać prawdę o jego losie i tym samym czyni ze swego podopiecznego przedmiot badań i dociekań, kierując się w zadaniu tym imperatywem dotarcia do prawdy, naprawienia krzywdy, zapewnienia osobie pokrzywdzonej przez państwo/ porządek Symboliczny ${ }^{12}$ poczucia (odebranej) podmiotowości.

W Foe trudno mówić o biowładzy państwa, choć oczywiście i władza Kruzo nad Piętaszkiem na wyspie, i automatyczne przypisanie Piętaszka statusowi niewolnika w Anglii, są formami władzy symbolicznej, tak samo jak państwo. 
Żadna z nich jednak nie zyskuje w procesie poznawania obiektu swoich dociekań przekonania o dobrze wykonanym zadaniu, nabierają one natomiast wątpliwości co do etyczności swojego pragnienia wiedzy, swojej relacji z podopiecznym i swojej roli w systemie, który go nadzoruje, izoluje i wykorzystuje. Sławomir Masłoń zauważa, że Coetzee stosuje motyw postaci „uciemiężonej” - ma tutaj na myśli prawdopodobnie też kategorię podmiotu podporządkowanego (subalterna), który „nie może mówić” [Spivak 1988: 25] - aby wprowadzić do narracji element ją komplikujący;

przemawianie w imieniu ofiary zawsze kończy się jej wykorzystaniem dla własnych celów $[\ldots]$ pisarz może użyć przedstawiciela uciemiężonych, by spróbować ukazać go jako kogoś, kogo znaczenie wymyka się autorskiej narracji. [Masłoń 2009: 73]

Masłoń co prawda odnosi to spostrzeżenie jedynie do Michaela K., lecz utrzymuje ono swą ważność dla pozostałych wymienionych tu powieści Coetzeego, w których postać o rysie autyzmu i/lub niepełnosprawności intelektualnej blokuje możliwość dopełnienia znaczenia narracji alegorią. Co ważne, Masłoń dostrzega, że takie autorskie alter ego, którego zadaniem jest pozyskać prawdę o postaci zniewolonej, uciemiężonej i podporządkowanej, to też etyczna pułapka autora trzech powieści - mimo że czytelnik ma wrażenie, że odmienność tych postaci zostaje uszanowana w ich nieczytelności oraz że uzyskują one w ten sposób autonomiczny status, jest to jedna $\mathrm{z}$ wielu, ironicznie podważona intertekstualnymi nawarstwieniami ${ }^{13}$, hermeneutyczna ścieżka. Daje ona komfort humanistycznego spełnienia, ponieważ pozwala na złudne poczucie, że niepełnosprawna, opresjonowana postać uzyskuje podmiotowość i autonomię. Coetzee jednak rzuca tę możliwość jedynie jako przynętę i proponuje o wiele bardziej radykalne odczytanie, które pokazuje nieuchronność impasu hermeneutycznego w procesie poznawania prawdy o podmiocie opresjonowa- 
nym, niezdolnym do reprezentowania siebie, poddanym zapisowi znaczeń z zewnątrz.

W Czekając na barbarzyńców dziewczyna, którą opiekuje się Sędzia, a która jest przedmiotem jego fascynacji potencjalnym znaczeniem jej okaleczonego ciała (rany jako inskrypcje na Realnym ciała), nie ma własnego głosu, nie wyraża siebie, jedynie imituje to, co chce się od niej usłyszeć. W efekcie Sędzia, myśląc o niej jako o mówiącej do niego, słyszy w istocie swoje pragnienie:

Dlaczego nie umiała znaleźć słów, żeby mi to wyjaśnić! „Nie tak trzeba to robić”, powinna powiedzieć, zatrzymując mnie w czasie pieszczot. [...] I potem, by mi nie odbierać nadziei, powinna mówić dalej. [Coetzee 1990: 209 tłum. zmienione]

Sędzia chce z dziewczyny uczynić podmiot sprawczy, aby odkupić swoją winę (którą odczuwa z powodu swojej pozycji w systemie imperium). Nie chce jednak zdać sobie sprawy, że jej „upodmiotowienie" nie jest możliwe, ponieważ w wyniku tortur - naznaczenia jej ciała znakiem Pana [Spivak 2009, 422], zostaje wyrzucona z porządku Symbolicznego jako podmiot i jest jedynie kodem nadpisanym na braku.

W Życiu i czasach Michaela K., oficera medycznego, który opiekuje się Michaelem K., a jednocześnie chce poznać jego przypadek, zastanawia źródło, z którego Michael K. czerpie „umiejętność” posłuszeństwa, które jest tak absolutne, że równie dobrze może być oporem. Dochodzi on do następującego wniosku: „obojętność Michaela na świat jako skutek pozostawania w stanie nienarodzenia" [Coetzee 2010: 80]. Masłoń proponuje udosłownić tę metaforę i pokazuje, że Michael, z powodu braku formującej triangulacji dziecko-ojciec-matka, czyli braku figury Ojca w swoim rozwoju, nie przechodzi do porządku Symbolicznego:

Ojciec wprowadza w tę wyobrażeniową relację język w formie zakazu i rozbija ją poprzez „socjalizację” dziecka za pomocą Prawa - dziecko musi zreorganizować swój świat wyobrażeniowy według standardów porządku symbolicznego, który jest światem języka i społecznych konwencji [Masłoń 2009: 82]. 
Masłoń „diagnozuje” Michaela następnie jako, nieuchronnie, psychotyka [Masłoń 2009: 84], którego problemy mają swoje źródło w niemożności operowania językiem jako metaforą (a właściwie, jako łańcuchami metafor). Psychotyk pozostaje w sferze Wyobrażeniowego, gdzie związek znaczącego i znaczonego może się w każdej chwili rozpaść, ponieważ nie został wzmocniony metaforą imienia Ojca. Nie mając do dyspozycji metafor, które kreują świat pojęć i wiążą podmiot ze światem społecznym jako systemem komunikacji, Michael K., ale tak samo Piętaszek z Foe oraz okaleczona dziewczyna z plemienia barbarzyńców z Czekając na barbarzyńców, pozostają w sferze powtarzalności i imitacji, swoistej fazie lustra. Postaci te, pozbawione dostępu do języka, kodu uruchamiającego znaczenia przez system substytucji (metafora) i przesunięć (metonimia), nie wchodzą w stan pragnienia, które jest niezbędnym elementem działania porządku Symbolicznego [Masłoń 2009: 90, 106]. U Michaela K. Masłoń widzi ten fundamentalny deficyt jako zwrot ku rozkoszy śmierci - wolność od porządku społecznego, która może wydać się w tej powieści spełnieniem marzenia o autonomicznym, wolnym podmiocie, jest tak naprawdę pragnieniem śmierci. Bunt Michaela K. to efekt uboczny jego absolutnego poddaństwa - tam, gdzie nie da się bardziej poddawać rozkazom, następuje śmierć, jedyna forma wyzwolenia. Piętaszek z Foe jest również figurą absolutnej nieodczytywalności informacji, którą niesie, jak spodziewa się Susan, przeciwnie do Kruzo i pisarza Daniela Foe, w swojej ukrytej, bo niewypowiedzianej, historii. Susan usilnie próbuje Piętaszka poznać, wierząc, że ucząc go wymiany jako podstawy komunikacji, będzie go w stanie nauczyć takiej formy wypowiedzi, która pozwoli jej go „przetłumaczyć”, przestransponować na język, jedyne narzędzie zdolne uchwycić materię prawdy Piętaszka. Jedną z technik jest próba przekierowania jego gry na flecie na system komunikacji. Nie udaje się jej, ponieważ, jak zauważa Masłoń, „Piętaszek nie gra dla nikogo oprócz samego siebie. Jego melodia to tylko oparcie dla popędów, umożliwiające im nieskończone krążenie wokół pustego centrum" [Masłoń 2009: 114]. Chęć Susan odzyskania znaczenia Piętaszka - historii i, nade wszystko, znaczenia jego okaleczenia opiera się na logice pragnienia, „które zawsze zwraca się do Innego 
i jest odpowiedzą Innemu" [Masłoń 2009: 115]. Susan oczekuje, że uda się jej wydobyć z Piętaszka jego własne pragnienie, na zasadzie bodźca komunikacyjnego, który, wysłany (jej wielorakie, całkiem pomysłowe, zachęty, aby Piętaszek wyraził cokolwiek - gestem, spojrzeniem, melodią, tańcem, pismem), musi wrócić $\mathrm{w}$ formie zwrotnego komunikatu. Podobnie jednak jak Michael K., Piętaszek pozostaje poza sferą pragnienia. Bardziej nawet niż Michael K., który jest w stanie korzystać z języka na zasadzie stosowania stałych, powtarzalnych fraz i obrazów, Piętaszek nie wyraża nic ani językiem, ani ciałem. Brak języka nie stanowi źródła tej absolutnej blokady; jest nim raczej brak posiadania systemu mowy. Piętaszek nie generalizuje słów bliskoznacznych: „Nauczyłem go słowa «drwa» - wyjaśnił Kruzo. - «Drewna» nie zna” [Coetzee 2007: 21]. Nie posiada też umiejętności odczytywania reprezentacji symbolicznej - obrazków ani graficznych reprezentacji pojęć, czyli pisma: „czy w rzeczy samej były to owe trzy litery, czy naprawdę oznaczały słowo «dom», a też mój obrazek i dom jako taki - jeden Piętaszek to wiedzial” [Coetzee 2007: 146]. Kikut języka, którego Susan się tak brzydzi, i które z kolei obrzydzenie przyprawia ją o poczucie winy, staje się w tej opowieści bardzo przewrotnym znaczącym. Masłoń widzi w okaleczeniu Piętaszka „pierwotny znak” [Coetzee 2007: 102], który pozwala Kruzo uczynić z Piętaszka idealnego poddanego w systemie Prawa, które za pomocą tego pierwotnego znaku ustanawia. Prawo wyspy, ustanowione przez Kruzo, jest o tyle bezsensowne, że jego praktyczna strona pokazuje brak jakiegokolwiek uchwytnego celu - terasy z ziemią pod uprawę, gdy nie ma czego uprawiać, są symbolem absolutnej arbitralności prawa. Brak organu mowy u Piętaszka oraz jego bardzo ograniczone rozumienie języka, którego uczy go Kruzo, ewidentnie figura Ojca, służy, w odczytaniu Masłonia, utrzymaniu władzy Kruzo, która zaczyna się wraz z uruchomieniem działania pierwotnego znaku jako znaczeniowości (okaleczenie jako „krwawe nacięcie, [które] ma na celu wpisanie w ciało prawa kultury" [Masłoń 2009: 103] przez zapomnienie (wyparcie) źródła okaleczenia.

Zaproponowane przez Masłonia Lacanowskie odczytanie funkcjonalności postaci opresjonowanych i podporządkowa- 
nych - postaci niepełnosprawnych u Coetzeego - przynosi bardzo ważne rozstrzygnięcie - postaci te, pozostające poza porządkiem Symbolicznym, dla których niedostępny jest świat komunikacji społecznej, a więc tym samym możliwość ich upodmiotowienia, to substancjalny przejaw Realnego. Przede wszystkim jawią się jako niezgłębiona tajemnica, która realizuje się w formie fantazmatów - postać niepełnosprawna jest możliwa jedynie jako fantazja przezwyciężenia swojej kondycji. Fantazja oczywiście to nic więcej niż łatwa do zdarcia zasłona oddzielającą podmiot od konfrontacji z Realnym. W tym sensie postać niepełnosprawna niesie ze sobą etyczne przesłanie odejścia od tautologicznej w istocie metaforyzacji (i metonimizacji) języka, który jedynie maskuje niemożność zapanowania nad materią i ukrywa monstrualność urzeczowienia. Oczywiście, jest to przesłanie dogłębnie przewrotne - jedność z naturą (Czekając na barbarzyńców), oczekiwanie Sędziego, że dziewczyna do niego wróci z „własnej woli”, ocalona z traumy odczłowieczenia (Czekając na barbarzyńców), oraz wiara Susan, że Piętaszek przełamie kiedyś swoje milczenie i wyrazi pragnienie (Foe), pozwalając jej wybawić swoje poczucie winy wypracowaniem opowieści (przerzuceniem pustki Realnego do łańcuchów metaforyzacji w języku), a kikut języka w ustach Piętaszka przestanie być jedyną rzeczą, którą Susan może od Piętaszka dostać, czyli monstrualną, nieusuwalną Rzeczą [Masłoń 2009: Słownik pojęć]. Jednak w tej ramie interpretacyjnej, doskonale obnażającej mechanizmy tworzenia symbolicznej przemocy, tak ważne w całej twórczości Coetzeego i równie fundamentalne dla literatury postkolonialnej jako zróżnicowanego zjawiska, trudno nie zauważyć faktu, że narzuca ona jeden, bardzo dychotomiczny, paradygmat hermeneutyczny, istotnie poddający w wątpliwość wszelkie pomysły na sprawczość, podmiotowość i scenariusze wolności dla grup opresjonowanych. Gdy nie zauważymy autystycznych cech Michaela K., zostanie on w istocie „psychotykiem”, czyli osobą niezdolną do utożsamienia się z językiem i utożsamienia znaczących z referentami w języku. Dziewczyna z Czekając na barbarzyńców pozostanie jedynie nieudaną próbą wyzwolenia się Sędziego z meandrów własnych uczuć i pragnień, zaś Piętaszek pozostanie nadzieją Susan na uchwycenie „materii” prawdy, która wymyka się 
jej w procesie pisania jego (i jej) historii. Jednak gdy podstawimy pod te figury niepowodzenia porządku Symbolicznego figurację autyzmu - postać nieprzetłumaczalną, pogrążoną w świecie afektów, wycofaną z życia społecznego jako strefy wymiany, dialogu i podmiotowości, zauważymy, że etyczność tych tekstów nie opiera się na ukazaniu nieuchronnego niepowodzenia porządku Symbolicznego, w tym porządku imperialnego, opresyjnego, totalitarnego, jako z góry skazanego na klęskę, a raczej na wydobyciu cech szczególnych danej niepełnosprawności jako blokady dla nadpisywania jej łańcuchami znaczeń - metafor, które mają służyć nie tyle podmiotowi niepełnosprawnemu, co wszystkim, którzy chcą na jego „braku” realizować swoje pragnienia hermeneutyczne.

Cisza podmiotu autystycznego, która w symbolicznym porządku opresji przez biowładzę stanowi podstawę dla umieszczenia osoby niepełnosprawnej w granicznej przestrzeni między ludzkim (będącym w logosie) i nie-ludzkim (pozbawionym mowy), a więc albo jest narzędziem porządku symbolicznego, albo symptomem Realnego, przestaje być negatywnością, gdy ukaże swój potencjał sprawczości. Nie chodzi tutaj o znaczenie ciszy, czyli ciszę jako część komunikatu, lecz o ucieleśnioną ciszę Innego, która kieruje nas na myślenie o pozajęzykowym kontakcie - przez afekt, dotyk, wzajemną obserwację zachowań, instynkt i intuicję, kontakt, który nie opisuje i nie zawłaszcza do języka. Kalpana Sheshadri, badając praktyki dehumanizacji jako odsunięcie Innego od języka, proponuje odwrócić kwestię języka i władzy, pytając:

Jak koncepcja ludzkiego (bycia w logosie) wyraża się jako władza? Jak dostrzec, że władza jest praktyką decydowania o tym, co jest ludzkie i co ludzkie nie jest? [...] Jak władza instrumentalizuje język i czy te dwie kategorie można w ogóle rozdzielić? [...] Co znaczy rozpoznać w ciszy władzę języka, a nie język władzy? [Sheshadri 2012: ix, przeł. D.K.]

Impas hermeneutyczny, który postać z autyzmem powoduje w tekście literackim i, szerzej, w świecie społecznym jako świecie komunikacji, nie powinien zostać przezwyciężony. Kwestionuje on bowiem etyczną podstawę metafory jako głównego sposobu 
„tłumaczenia” niepełnosprawności i radykalnej odmienności i, jako taki, jest sygnałem konieczności znalezienia sposobu mówienia autyzmem, niepełnosprawnością czy traumą, a nie mówienia za nie lub w ich imieniu.

\section{Bibliografia:}

Benhabib Seila (2002), The Claims of Culture: Equality and Diversity in the Global Era, Princeton UP, Princeton [Stany Zjednoczone].

Butler Judith (1993), Bodies that Matter: On the Discursive Limits of „Sex”, Routledge, New York [Stany Zjednoczone].

Coetzee J.M. (2007), Foe, przeł. Magdalena Konikowska, Wydawnictwo Znak, Kraków.

Coetzee, J.M. (1990), Czekając na barbarzyńców, przeł. Anna Mysłowska, Czytelnik, Warszawa.

Coetzee, J.M. (2010), Życie i czasy Michaela K., przeł. Magdalena Konikowska, Znak, Kraków.

Davis Lennard J., Constructing Normalcy. The Bell Curve, the Novel, and the Invention of the Diasbled Body in the $19^{\text {th }} \mathrm{c}$., w: Disability Studies Reader, red. Lennard J. Davis, Routledge, New York [Stany Zjednoczone], s. 3-16.

Davis Lennard J. red. (2006), The Disability Studies Reader, Routledge, New York [Stany Zjednoczone].

Davis Lennard J. (2006), Introduction, w: Disability Studies Reader, red. Lennard J. Davis, Routledge, New York [Stany Zjednoczone], s. xv-xviii.

Foucault Michel $(1967 ; 1984)$, Of Other Spaces: Utopias and Heterotopias [online], w: Architecture /Mouvement/ Continuité, October 1984, „Des Espace Autres”, marzec 1967, przeł. Jay Miskowiec, s. 5, www.web.mit.edu, [dostęp: 10 października 2016].

Glotfelty Cheryll, Fromm Harold, red. (1996), The Ecocrticism Reader. Landmarks in Literary Ecology, University of Georgia Press, Athens [Stany Zjednoczone].

Graham Huggan, Tiffin Helen red. (2010) Postcolonial Ecocriticism: Literature, Animals, Environment, Routledge, London [Wielka Brytania].

Jameson Fredric (1986), Third World Literature in the Era of Multinational Capitalism, „Social Text”, no 15, s. 65-88.

Lacan Jacques, (1973) Le séminaire. Livre XI. Les quatre concepts fondamentaux de la psychanalyse, Seuil, Paris [Francja]. 
Masłoń Sławomir (2009), Coetzee. Przewodnik Krytyki Politycznej, Wydawnictwo Krytyki Politycznej, t. 11, Warszawa.

Mitchell David, Snyder Sharon (2006), Narrative Prosthesis and the Materiality of Metaphor, w: The Disability Studies Reader, red. Lennard J. Davis, Routledge, New York [Stany Zjednoczone], s. 205-216.

Moe Aaron M. (2016), The Work of Literature in a Multispecies World, $\mathrm{w}$ : The Educational Significance of Human and Non-Human Animal Interactions. Blurring the Species Line, red. Suzanne Rice, Anthony G. Rudd, Palgrave Macmillan, London [Wielka Brytania], s. 133-149.

Murray Stuart (2008), Representing Autism. Culture, Narrative, Fascination, Liverpool University Press, Liverpool [Wielka Brytania].

Osteen Mark (2008), Autism and Representation, Routledge, London [Wielka Brytania].

Parker Ian, (2015), Psychology After Lacan: Connecting the Clinic and Research, Routledge, New York [Stany Zjednoczone].

Quayson Ato (2007), Aesthetic Nervousness: Disability and the Crisis of Representation, Columbia UP, New York [Stany Zjednoczone]. Rushdie Salman (200o), Wstyd, przeł. Mariusz Ferek, Rebis, Poznań. Sheshadri Kalpana Rahita (2012), HumAnimal. Race, Law, Language, University of Minnesota Press, Minnesota [Stany Zjednoczone].

Siebers Tobin (2006), On the Government of Disability: Foucault, Power, and the Subject Impairment, w: The Disability Studies Reader, red. Lennard J. Davis, Routledge, New York [Stany Zjednoczone], s. $173-184$.

Spivak Gayatri Chakravorty (1988), Can the Subaltern Speak?, w: Marxism and the interpretation of Culture, red. Cary Nelson, Lawrence Grossberg, University of Illinois Press, Chicago [Stany Zjednoczone], s. 271-313.

Spivak Gayatri Chakravorty (2009), Polityka przekładu, przeł. Dorota Kołodziejczyk, w: Wspótczesne teorie przedkładu, red. Magda Heydel i Piotr Bukowski, Znak, Kraków, s. 403-427.

Dorota Kołodziejczyk

Beyond the metaphor - autism as a hermeneutical impasse in postcolonial novels

A lot of postcolonial novels feature characters with disordered communication, unable to express their will, existing outside of language. These most often unnamed traces of autism and/or intellectual disability become in 
fictional narrative an element disturbing the expected outcome of postcolonial vindications, out of which the most important is regaining by a marginalized character the sense of subjectivity, realized as a possibility to tell one's own story. Basing on Ato Quayson's concept of “aesthetic nervousness", the article traces how literary and cultural representations of disability introduce into a text affective-cognitive mechanisms which reveal, as Ato Quayson says, "heremeneutic impasse" caused by a confrontation of the norm with disability. This blocked path of text interpretation poses the radical example of untranslatability which will not be abated or compensated by the effort to substitute lack represented by the autistic subject (lack of speech, communication, subjectivity - in general - lack of participation in the universe of interlocution, as Seyla Benhabib calls it). Hermeneutic impasse is, then, inscribed in the very narrative structure featuring an autistic character. On the basis of J.M. Coetzee's novels, the article analyses this impasse as resistance that untranslatability poses against the attempts to understand, that is, represent, such a subject. These attempts, ethical as to their purpose, end up, however, in containment.

Keywords: autism; hermeneutic impasse; aesthetic nervousness; disability; communication; untranslatability.

Dorota Kołodziejczyk - adiunkt w Instytucie Filologii Angielskiej na Uniwersytecie Wrocławskim, kierownik Pracowni Badań Postkolonialnych, członkini Rady Naukowej Centrum Badań Dyskursów Postzależnościowych, współzałożycielka międzynarodowej sieci badawczej Centrum Badań Postkolonialno-Posttotalitarnych na Wydziale Filologicznym uwr. Autorka publikacji z zakresu studiów postkolonialnych, powieści i teorii powieści, komparatystyki oraz teorii przekładu, np.: z Cristiną Şandru, numer specjalny pisma The Journal of Postcolonial Writing pt. Postcolonialism/ Postcommunism: confluences, intersections and discontents, 2012, reprint pt. Postcolonial Perspectives on Postcommunism in Central and Eastern Europe, Routledge 2016; z Hanną Gosk: Historie, społeczeństwa, przestrzenie dialogu - studia postzależnościowe $w$ perspektywie porównawczej, Universitas 2014; tłumaczka tekstów $\mathrm{z}$ zakresu teorii postkolonialnej. 
